Article

\title{
Effect of Reduction Atmosphere on Structure and Catalytic Performance of PtIn/Mg(Al)O/ZnO for Propane Dehydrogenation
}

\author{
Ming Zhang ${ }^{1}$, Zhen Song ${ }^{1}$, Mengquan Guo ${ }^{1}$, Xiangxiang Li ${ }^{1}$, Yanjun Lin ${ }^{2, *}$ and \\ Lihong Zhang ${ }^{1, * \mathbb{D}}$ \\ 1 Department of Catalysis Science and Technology and Tianjin Key Laboratory of Applied Catalysis Science \\ Technology, School of Chemical Engineering and Technology, Tianjin University, Tianjin 300350, China; \\ minne_zhang@hotmail.com (M.Z.); songzhens12345@163.com (Z.S.); Guo_mengquan@163.com (M.G.); \\ lixx_37@tju.edu.cn (X.L.) \\ 2 State Key Laboratory of Chemical Resource Engineering, Beijing University of Chemical Technology, \\ Beijing 100029, China \\ * Correspondence: linyj@mail.buct.edu.cn (Y.L.); zlh_224@163.com (L.Z.); \\ Tel.: +86-136-4138-6787 (Y.L.); +86-150-2225-5828 (L.Z.)
}

Received: 17 March 2020; Accepted: 24 April 2020; Published: 29 April 2020

\begin{abstract}
The effect of reduction atmospheres, $\mathrm{H}_{2} / \mathrm{N}_{2}, \mathrm{C}_{3} \mathrm{H}_{8} / \mathrm{H}_{2} / \mathrm{N}_{2}, \mathrm{C}_{3} \mathrm{H}_{8}$ and $\mathrm{CO}$, on the structure and propane direct dehydrogenation performance of $\mathrm{PtIn} / \mathrm{Mg}(\mathrm{Al}) \mathrm{O} / \mathrm{ZnO}$ catalyst derived from $\mathrm{ZnO}$-supported PtIn-hydrotalcite was studied. The physicochemical properties of the as-prepared and used catalytic system were characterized by various characterization methods. The results show that the dehydrogenation performance, especially the stability of the $\mathrm{PtIn} / \mathrm{Mg}(\mathrm{Al}) \mathrm{O} / \mathrm{ZnO}$ catalyst, was significantly improved along with the change in reduction atmosphere. The highest catalytic activity (51\% of propane conversion and 97\% propylene selectivity), resistance toward coke deposition, and stability for more than $30 \mathrm{~h}$ were achieved with the $\mathrm{H}_{2} / \mathrm{N}_{2}$-reduced catalyst. The optimal dehydrogenation performance and coke resistance are mainly related to the high $\mathrm{Pt}$ dispersion and $\mathrm{In}^{0} / \mathrm{In}^{3+}$ molar ratio, strong $\mathrm{Pt}-\mathrm{In}$ interaction and small metal particle size, depending on the nature of the reduction atmospheres. The reconstruction of meixnerite favors the stability and coke resistance to some extent.
\end{abstract}

Keywords: propane dehydrogenation; reduction atmosphere; coke deposition; meixnerite; $\mathrm{PtIn} / \mathrm{Mg}(\mathrm{Al}) \mathrm{O} / \mathrm{ZnO}$

\section{Introduction}

In recent years, the dehydrogenation of low alkanes to the corresponding alkenes has drawn great attention from the world, due to their extensive utilization as raw materials and a versatile class of intermediates in the polymer industry. In this context, it is particularly important to dehydrogenate propane to propylene $(\mathrm{PDH})$ because of the rapidly growing demand for propylene in the production of propylene oxide, acrylonitrile and polypropylene [1-3]. The preparation and structure studies of catalysts with high efficiency propylene yield become the key point of PDH.

At present, Al-Cu catalysts, $\mathrm{Co} / \mathrm{SiO}_{2}$ catalysts, Ce-based catalysts, etc., are mainly novel catalysts developed by researchers [4-6]. However, Pt-based catalysts are still regarded as the most effective catalysts for PDH process, especially when working with a promoter, such as In, Sn, Ga or Zn, which can further improve propylene selectivity [1,7-10].

The support materials, $\mathrm{Al}_{2} \mathrm{O}_{3}[11], \mathrm{SiO}_{2}[6], \mathrm{ZrO}_{2}[12,13]$ and zeolite [3,14], can also affect catalytic performance on account of the significant differences in textural properties. Especially, the $\mathrm{Mg}(\mathrm{Al}) \mathrm{O}$ 
oxides obtained by calcining hydrotalcite compounds (HT) have been studied extensively during the past years, owing to their suitable acid-base properties, high thermal stability, large surface area and memory effect [15-23]. Simultaneously, the stability of support plays an important role in reactions. Many works have been tried to stabilize the HT-based catalysts by combining with graphene networks $[17,24]$, growing on metal $(\mathrm{Al}, \mathrm{Ni})$ or alloy substrates $[25,26]$ and loading on oxide materials $\left(\gamma-\mathrm{Al}_{2} \mathrm{O}_{3}, \mathrm{ZnO}, \mathrm{SnO}_{2}\right)$ [27-29].

It is well known that the activity of $\mathrm{PDH}$ is susceptible to many factors. Some researchers have studied the preparation conditions of $\mathrm{Mg}(\mathrm{Al}) \mathrm{O}$ support, such as $\mathrm{Mg} / \mathrm{Al}$ molar ratio, $\mathrm{pH}$ value, and calcination temperature of the HT precursor $[19,21,30,31]$. Others have discussed the effect of loading methods and precursors of Pt on PDH $[32,33]$. Still others investigated the dehydrogenation reaction conditions (temperature, co-feed gas), In/Pt molar ratio and formation of PtIn alloy [15,34,35]. Most of the factors have been studied in detail. However, this does not seem to be the case for the reduction atmosphere of $\mathrm{Mg}(\mathrm{Al}) \mathrm{O}$-supported Pt-based catalysts. Thus, the relationships between reduction atmosphere and catalysts' performance deserve to be studied.

In this paper, the influence of reduction atmospheres on the structural properties and catalytic performance of the PtIn/Mg(Al)O/ZnO (PtIn/MAZ) catalytic system was studied. $\mathrm{ZnO}$ was employed as the support for PtIn/Mg(Al)O catalytic system on account of its good stability. On this basis, $\mathrm{ZnO}$-supported HT was prepared by the hydrothermal method, then In and Pt elements were introduced into the HT layer by sequential impregnation-induced reconstruction. $\mathrm{H}_{2} / \mathrm{N}_{2}, \mathrm{C}_{3} \mathrm{H}_{8} / \mathrm{H}_{2} / \mathrm{N}_{2}$, $\mathrm{C}_{3} \mathrm{H}_{8}$ and $\mathrm{CO}$ were selected as the reduction atmospheres, which are commonly used or produced in the reaction and likely to affect the catalytic performance. The precursors, calcined samples and reduced catalytic system were characterized by X-ray diffraction (XRD), transmission electron microscopy (TEM), X-ray photoelectron spectroscopy (XPS), thermogravimetric (TG) and CO chemisorption. The $\mathrm{PDH}$ reaction was performed at $600^{\circ} \mathrm{C}$ and atmospheric pressure with the gas mixture of $\mathrm{C}_{3} \mathrm{H}_{8}$, $\mathrm{H}_{2}$ and $\mathrm{N}_{2}$.

\section{Results and Discussion}

\subsection{Catalytic Activity}

A series of PtIn/MAZ reduced with different atmospheres $\left(\mathrm{H}_{2} / \mathrm{N}_{2}, \mathrm{C}_{3} \mathrm{H}_{8} / \mathrm{H}_{2} / \mathrm{N}_{2}, \mathrm{C}_{3} \mathrm{H}_{8}\right.$ and $\left.\mathrm{CO}\right)$ at $600{ }^{\circ} \mathrm{C}$ for $2.5 \mathrm{~h}$ were evaluated in $\mathrm{PDH}$ reaction, and their propane conversions and propylene and by-product selectivities as a function of time on stream are shown in Figure 1. During the $17 \mathrm{~h}$ on stream, propane conversion and propylene selectivity showed an obvious improvement with the reduction atmosphere changing from $\mathrm{CO}$ to $\mathrm{C}_{3} \mathrm{H}_{8}$ and to $\mathrm{C}_{3} \mathrm{H}_{8} / \mathrm{H}_{2} / \mathrm{N}_{2}$. This should arise from the different surface chemical states of the active metal species. An "induction period" appeared for all samples, especially the activity of the CO-reduced sample, which had a long induction period. This can be explained by the in-situ creation of the active metal species [11]. Additionally, it was found that there nearly no cracking products were formed on the samples reduced with $\mathrm{C}_{3} \mathrm{H}_{8}$ and $\mathrm{C}_{3} \mathrm{H}_{8} / \mathrm{H}_{2} / \mathrm{N}_{2}$ during the period of $\sim 17 \mathrm{~h}$. However, the CO-reduced sample had more cracking products at the initial stage and presented a decreasing tendency with time on stream, together with ascending propylene selectivity. This agrees with the phenomenon that $\mathrm{CO}$ pre-reduction can result in violent cracking at the initial stage $[36,37]$. Furthermore, the replacement of $\mathrm{C}_{3} \mathrm{H}_{8} / \mathrm{H}_{2} / \mathrm{N}_{2}$ by $\mathrm{H}_{2} / \mathrm{N}_{2}$ slightly decreased the conversion but enhanced the initial activity and catalytic stability. Nevertheless, there were no obvious difference between their propylene and by-product selectivities during the reaction lasting for $17 \mathrm{~h}$. 

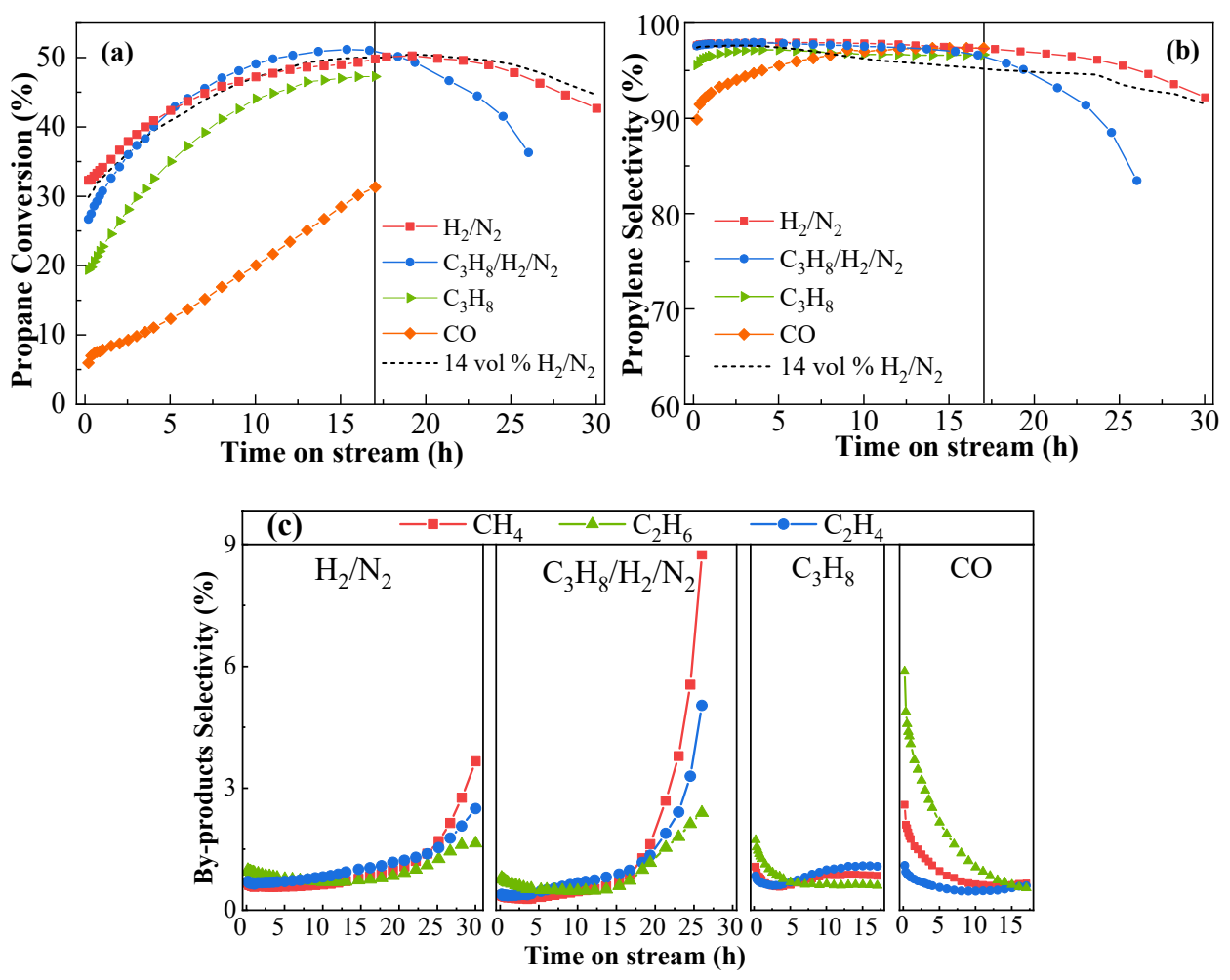

Figure 1. Catalytic performances of PtIn/MAZ catalytic system reduced with different atmospheres: (a) propane conversion; (b) propylene selectivity; (c) by-product selectivity (reduction conditions: $\mathrm{T}=600{ }^{\circ} \mathrm{C}, \mathrm{t}=2.5 \mathrm{~h}$; reaction conditions: $\mathrm{T}=600^{\circ} \mathrm{C}$, weight hourly space velocity $(\mathrm{WSHV})=3 \mathrm{~h}^{-1}$, atmospheric pressure in the gas mixture of $\mathrm{C}_{3} \mathrm{H}_{8}: \mathrm{H}_{2}: \mathrm{N}_{2}$ molar ratio = 8:7:35; reaction time: $30 \mathrm{~h}$ for $\mathrm{H}_{2} / \mathrm{N}_{2}$ and $14 \mathrm{vol} \% \mathrm{H}_{2} / \mathrm{N}_{2}$ reduced catalyst, $26 \mathrm{~h}$ for $\mathrm{C}_{3} \mathrm{H}_{8} / \mathrm{H}_{2} / \mathrm{N}_{2}$-reduced catalyst, $17 \mathrm{~h}$ for $\mathrm{C}_{3} \mathrm{H}_{8}$ and CO-reduced catalyst).

Since the activities of $\mathrm{C}_{3} \mathrm{H}_{8} / \mathrm{H}_{2} / \mathrm{N}_{2}$ - and $\mathrm{H}_{2} / \mathrm{N}_{2}$-reduced catalytic systems were much higher than those of the others, the reaction time was extended to $30 \mathrm{~h}$ to compare the stability of the $\mathrm{C}_{3} \mathrm{H}_{8} / \mathrm{H}_{2} / \mathrm{N}_{2}-$ and $\mathrm{H}_{2} / \mathrm{N}_{2}$-reduced catalytic systems. When the reaction time was prolonged, some distinct and significant differences could be found between them. With a reaction of $30 \mathrm{~h}$, the propane conversion and propylene selectivity of $\mathrm{H}_{2} / \mathrm{N}_{2}$-reduced samples were maintained at more than $45 \%$ and $92 \%$ and the by-product selectivity was less than $4 \%$, respectively. However, the $\mathrm{C}_{3} \mathrm{H}_{8} / \mathrm{H}_{2} / \mathrm{N}_{2}$-reduced catalyst showed a rapid decrease of propane conversion and propylene selectivity after $18 \mathrm{~h}$ along with the increase of cracking products. In order to evaluate the effect of $\mathrm{H}_{2}$ content, the $14 \mathrm{vol} \%$ $\mathrm{H}_{2} / \mathrm{N}_{2}$ with the same $\mathrm{H}_{2}$ content as $\mathrm{C}_{3} \mathrm{H}_{8} / \mathrm{H}_{2} / \mathrm{N}_{2}$ was also adopted for the comparison. It is noticeable that the propane conversion and propylene selectivity of the $14 \mathrm{vol} \% \mathrm{H}_{2} / \mathrm{N}_{2}$-reduced sample was similar to that of the $\mathrm{H}_{2} / \mathrm{N}_{2}$-reduced one. This indicates that the reducibility of $\mathrm{H}_{2} / \mathrm{N}_{2}$ is quite similar to that of $14 \mathrm{vol} \% \mathrm{H}_{2} / \mathrm{N}_{2}$ under this reduction temperature. Therefore, the different performance between $\mathrm{H}_{2} / \mathrm{N}_{2}$ and $\mathrm{C}_{3} \mathrm{H}_{8} / \mathrm{H}_{2} / \mathrm{N}_{2}$ is arising from the presence of $\mathrm{C}_{3} \mathrm{H}_{8}$ in $\mathrm{C}_{3} \mathrm{H}_{8} / \mathrm{H}_{2} / \mathrm{N}_{2}$, which makes the $\mathrm{C}_{3} \mathrm{H}_{8} / \mathrm{H}_{2} / \mathrm{N}_{2}$-reduced sample rapidly deactivate along with the increase of cracking products. Meanwhile, the $\mathrm{H}_{2} / \mathrm{N}_{2}$-reduced sample had effective catalytic stability and crack resistance.

\subsection{Texture and Structure of Reduced Catalystic Systems}

\subsubsection{XRD}

According to the XRD patterns of precursors and calcined samples obtained with different preparation processes in Figure S1, it could be confirmed that the HT phase can be formed on the $\mathrm{ZnO}$ precursor (hydrozincite phase, JCPDS file No. 19-1458); even the ZnO-supported PtIn-HT can be acquired by impregnation-induced reconstruction. After calcination, only $\mathrm{MgO}$ phases (JCPDS file 
No. 87-0651) could be indexed on $\mathrm{ZnO}$ (JCPDS file No. 75-0576). The $\mathrm{Al}_{2} \mathrm{O}_{3}$ diffraction peaks could not be found, as it is retained and located in interstitial sites in the $\mathrm{MgO}$ framework after calcination [38]. There were no diffraction peaks of Pt-(In-)-based compounds, as a result of their low concentration or uniform distribution [38].

In order to evaluate the crystalline phase of the reduced PtIn/MAZ catalytic system, XRD characterization was conducted, and the results are shown in Figure 2. It can be noted that the XRD patterns of all samples show the same crystalline diffraction peaks. The main crystalline phases were $\mathrm{ZnO}$ and $\mathrm{MgO}$ and the peaks were same with those of calcined ones (Figure S1B). This means the change in reduction atmosphere did not cause the obvious change of crystal phases. The diffraction peaks of $\mathrm{Pt}(\mathrm{In})$-species still could not be recognized for the reduced PtIn/MAZ catalytic system. This is owing to the small and uniform distribution of $\mathrm{Pt}(\mathrm{In})$ species on the support or the low concentration [19].

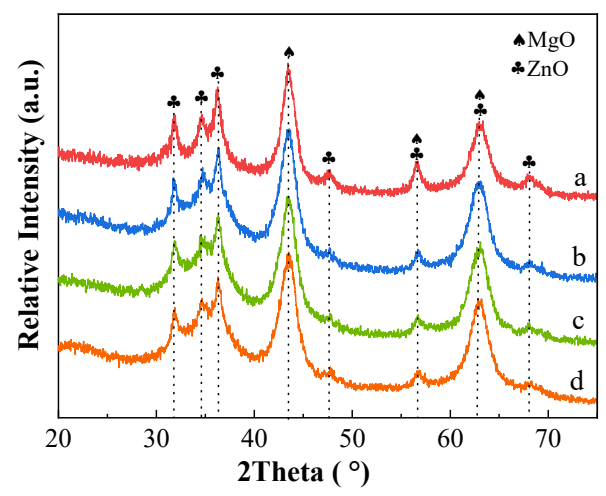

Figure 2. XRD patterns of PtIn/MAZ catalytic systems reduced with different atmospheres: (a) $\mathrm{H}_{2} / \mathrm{N}_{2}$; (b) $\mathrm{C}_{3} \mathrm{H}_{8} / \mathrm{H}_{2} / \mathrm{N}_{2}$; (c) $\mathrm{C}_{3} \mathrm{H}_{8}$; (d) $\mathrm{CO}$ (reduction conditions: $\mathrm{T}=600{ }^{\circ} \mathrm{C}, \mathrm{t}=2.5 \mathrm{~h}$ ).

\subsubsection{TEM}

The morphology, phase composition and particle size distribution (PSD) of the reduced catalytic system are given in Figure 3. Although it is difficult to distinguish the diffraction of metallic phases from the XRD patterns in Figure 1, the metallic Pt (111) nanoparticles (NPs) can be recognized in the HR-TEM depending on the lattice spacing of $0.226 \mathrm{~nm}$. Meanwhile, PtIn alloy $(\mathrm{d}=0.208 \mathrm{~nm}) \mathrm{can}$ be detected on the $\mathrm{H}_{2} / \mathrm{N}_{2}$-reduced sample. From the PSD of all samples, the average particle size of metals was in the range from $0.85-1.20 \mathrm{~nm}$. The small metal NPs can be related to the PtIn-HT reconstruction, as described in Figure S1. Moreover, the average metal particle sizes of $\mathrm{H}_{2} / \mathrm{N}_{2}$ - and $\mathrm{C}_{3} \mathrm{H}_{8} / \mathrm{H}_{2} / \mathrm{N}_{2}$-reduced samples are smaller than that of $\mathrm{C}_{3} \mathrm{H}_{8}$ - and CO-reduced ones. This indicates that the $\mathrm{H}_{2}$-containing reduction gas is more efficient to obtain smaller metallic particles. The smaller metal particles are more active for propane dehydrogenation performance and beneficial to resist the coke deposition [39].
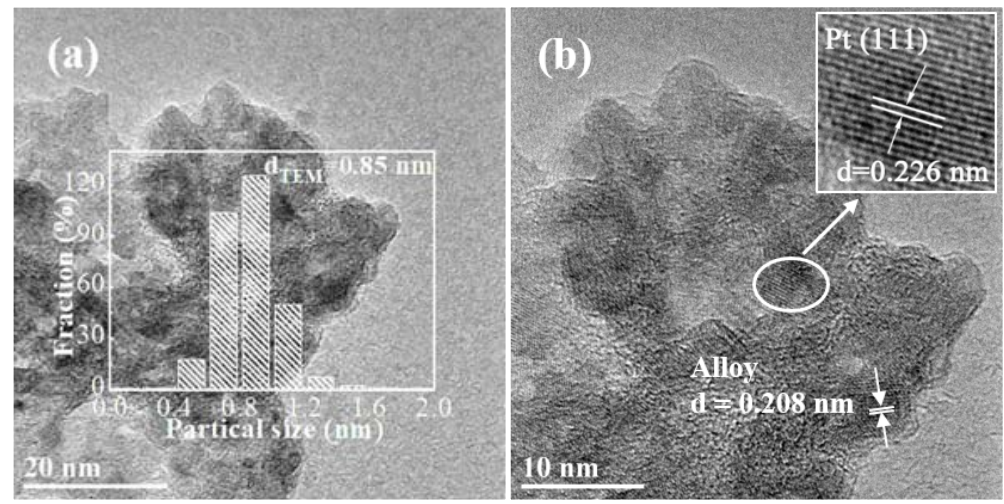

Figure 3. Cont. 

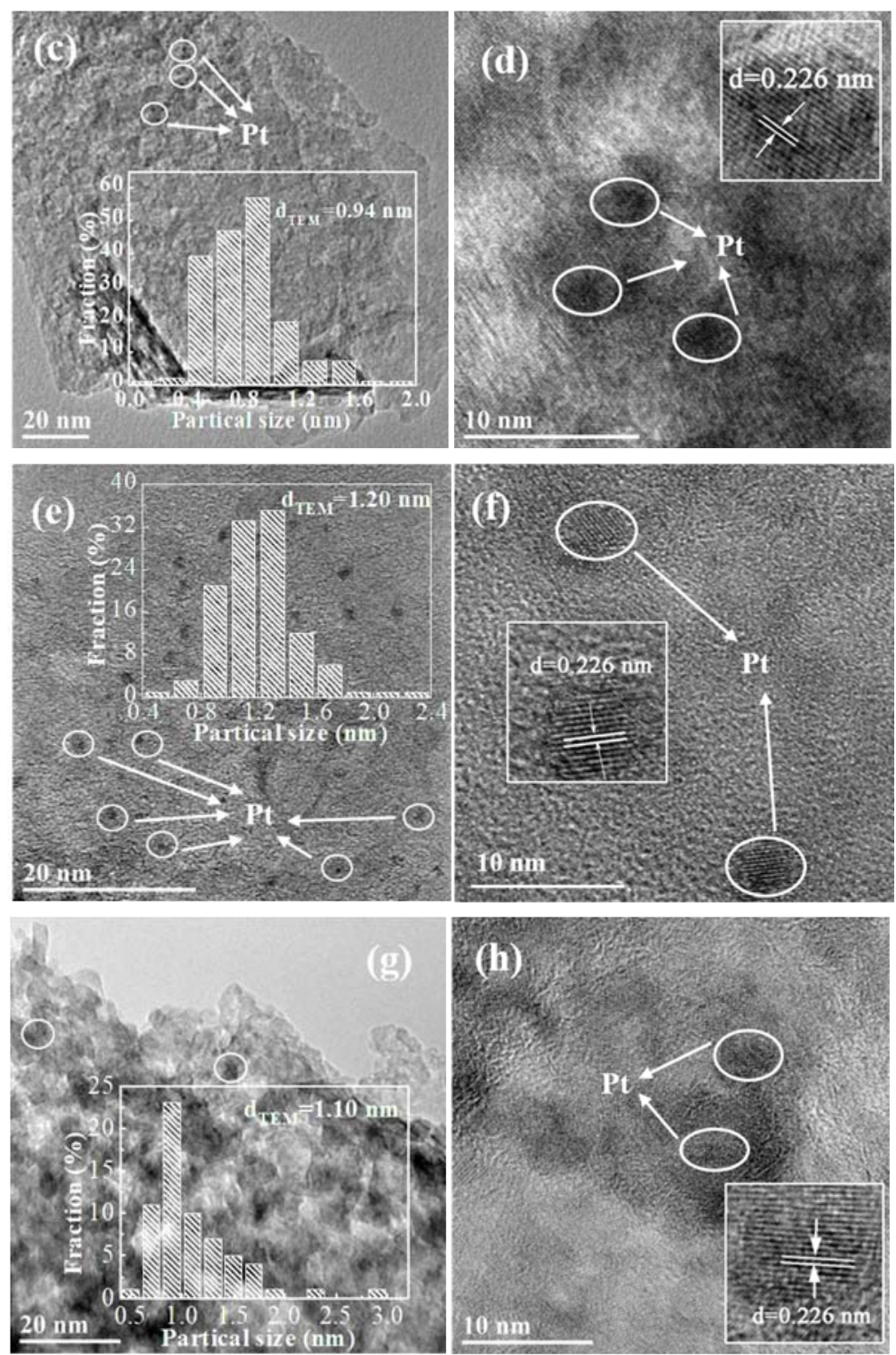

Figure 3. TEM images, HR-TEM and the statistics of PSD in the insets of PtIn/MAZ catalytic system reduced with different atmospheres: (a,b) $\mathrm{H}_{2} / \mathrm{N}_{2} ;(\mathbf{c}, \mathbf{d}) \mathrm{C}_{3} \mathrm{H}_{8} / \mathrm{H}_{2} / \mathrm{N}_{2} ;(\mathbf{e}, \mathbf{f}) \mathrm{C}_{3} \mathrm{H}_{8} ;(\mathbf{g}, \mathbf{h}) \mathrm{CO}$ (reduction conditions: $\mathrm{T}=600^{\circ} \mathrm{C}, \mathrm{t}=2.5 \mathrm{~h}$ ).

\subsubsection{XPS}

The chemical states of In species over the reduced catalytic system were determined by XPS measurements. The $\mathrm{Pt} 4 \mathrm{f}$ spectra is not shown here due to the difficulty of distinguishing it from the $\mathrm{Al}$ $2 p$ peak [40]. The XPS spectra of the In $3 \mathrm{~d}_{5 / 2}$ region are shown in Figure 4 , and the semi-quantitative results of the corresponding spectra are summarized in Table 1 . The In $3 \mathrm{~d}_{5 / 2}$ level can be split into two peaks at $\sim 444.1 \mathrm{eV}$ and $\sim 445.2 \mathrm{eV}$, which represent $\operatorname{In}^{0}$ (metallic $\mathrm{In}$ or PtIn alloy) and $\mathrm{In}^{3+}$, respectively. As shown in Table 1, the $\operatorname{In}^{0} / \mathrm{In}^{3+}$ molar ratios for $\mathrm{H}_{2} / \mathrm{N}_{2},-, \mathrm{C}_{3} \mathrm{H}_{8} / \mathrm{H}_{2} / \mathrm{N}_{2^{-}}, \mathrm{C}_{3} \mathrm{H}_{8^{-}}$and CO-reduced samples were 2.50, 1.22, 0.59 and 0.78 , respectively. According to the downward trend of the $\mathrm{In}^{0} / \mathrm{In}^{3+}$ molar ratio from $\mathrm{H}_{2} / \mathrm{N}_{2}$ to $\mathrm{C}_{3} \mathrm{H}_{8} / \mathrm{H}_{2} / \mathrm{N}_{2}$ and to $\mathrm{C}_{3} \mathrm{H}_{8}$, it is assumed that the presence of $\mathrm{C}_{3} \mathrm{H}_{8}$ can impede the formation of zero-valence In. The deduction is based on the similar reducibility between $\mathrm{H}_{2} / \mathrm{N}_{2}$ and $14 \mathrm{vol} \% \mathrm{H}_{2} / \mathrm{N}_{2}$, which has been proved by the corresponding catalytic performance in Figure 1. In view of this, the $\operatorname{In}^{0} / \mathrm{In}^{3+}$ molar ratio in the $\mathrm{C}_{3} \mathrm{H}_{8} / \mathrm{H}_{2} / \mathrm{N}_{2}$-reduced sample should be equal to or higher than that of the $\mathrm{H}_{2} / \mathrm{N}_{2}$-reduced one, due to the co-existence of $\mathrm{H}_{2}$ and $\mathrm{C}_{3} \mathrm{H}_{8}$. The opposite 
results indicate that the $\mathrm{C}_{3} \mathrm{H}_{8}$ must impede the reduction of $\mathrm{In}^{3+}$ ions. In this way, it is not difficult to understand why the $\mathrm{In}^{0} / \mathrm{In}^{3+}$ molar ratio of CO-reduced sample was higher than $\mathrm{C}_{3} \mathrm{H}_{8}$-reduced one. The $\mathrm{In}^{0} / \mathrm{In}^{3+}$ molar ratio of the CO-reduced sample was lower than that of $\mathrm{H}_{2}$-containing reduced sample, indicating that the reduction ability of $\mathrm{CO}$ to $\mathrm{In}^{3+}$ was weaker than that of $\mathrm{H}_{2}$. The $\mathrm{In}^{0}$ has been proved to promote the transfer of coke from the active site to the support and the stabilization of the active metal species $[40,41]$. Meanwhile, the presence of $\mathrm{C}_{3} \mathrm{H}_{8}$ leads to a decrease of $\mathrm{In}^{0}$, thus the propylene selectivity of the $\mathrm{H}_{2} / \mathrm{N}_{2-}^{-}, \mathrm{C}_{3} \mathrm{H}_{8} / \mathrm{H}_{2} / \mathrm{N}_{2}$ - and $\mathrm{C}_{3} \mathrm{H}_{8}$-reduced catalytic systems decreases accordingly (see Figure 1).

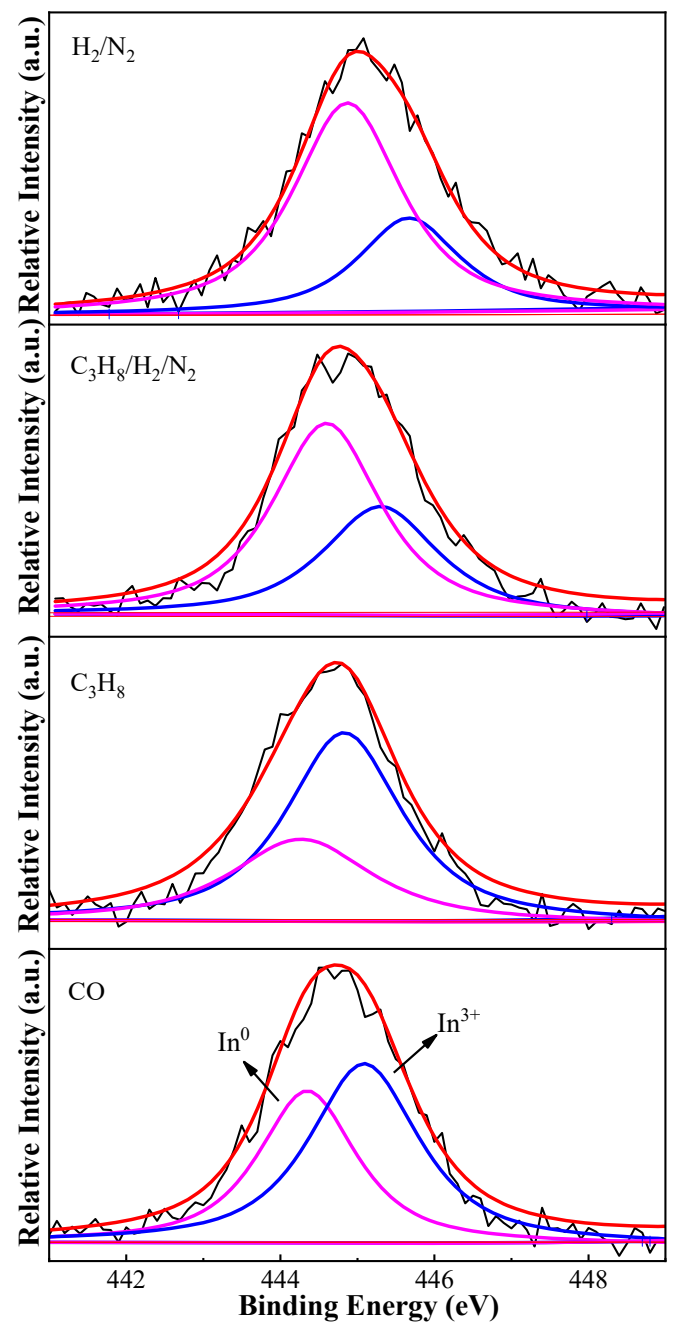

Figure 4. In $3 d_{5 / 2}$ XPS spectra of a PtIn/MAZ catalytic system reduced with different atmospheres (reduction conditions: $\mathrm{T}=600^{\circ} \mathrm{C}, \mathrm{t}=2.5 \mathrm{~h}$ ).

Table 1. XPS results and Pt dispersion of a PtIn/MAZ catalytic system reduced with different atmospheres ${ }^{\text {a }}$ (reduction conditions: $\mathrm{T}=600^{\circ} \mathrm{C}, \mathrm{t}=2.5 \mathrm{~h}$ ).

\begin{tabular}{ccccc}
\hline $\begin{array}{c}\text { Reduction } \\
\text { Atmosphere }\end{array}$ & \multicolumn{2}{c}{ Binding Energy (eV) } & $\begin{array}{c}\mathbf{I n}^{\mathbf{0}} / \mathbf{I n}^{3+} \\
\text { Molar Ratio }\end{array}$ & $\begin{array}{c}\text { Pt } \\
\text { Dispersion }^{\mathbf{c}}\end{array}$ \\
\cline { 2 - 3 } $\mathbf{I n}^{\mathbf{3}}$ & 444.9 & 445.7 & 2.50 & $48 \%$ \\
$\mathrm{H}_{2} / \mathrm{N}_{2}$ & 444.5 & 445.2 & 1.22 & $34 \%$ \\
$\mathrm{C}_{3} \mathrm{H}_{8} / \mathrm{H}_{2} / \mathrm{N}_{2}$ & 444.3 & 444.8 & 0.59 & - \\
$\mathrm{C}_{3} \mathrm{H}_{8}$ & 444.4 & 445.1 & 0.78 & - \\
$\mathrm{CO}$ &
\end{tabular}

a All samples were protected with Ar from oxidation prior to test. ${ }^{b}$ Calculated from the fitting peak area results of In $3 d_{5 / 2}$ XPS spectra. ${ }^{c}$ Computed from the CO chemisorption results. 
The binding energy (BE) value of $\operatorname{In}^{0}$ presented a slightly decreasing trend in accordance with the order of $\mathrm{H}_{2} / \mathrm{N}_{2^{-}}, \mathrm{C}_{3} \mathrm{H}_{8} / \mathrm{H}_{2} / \mathrm{N}_{2^{-}}, \mathrm{CO}$ - and $\mathrm{C}_{3} \mathrm{H}_{8}$-reduced samples, signifying the weakening Pt-In interaction and transfer of electrons from metallic In to Pt species [22]. The electron-rich Pt sites are beneficial to hindering the adsorption of alkenes on active sites, consequently decreasing the likelihood of hydrogenolysis and coking [42].

The Pt dispersion of $\mathrm{H}_{2} / \mathrm{N}_{2}$ - and $\mathrm{C}_{3} \mathrm{H}_{8} / \mathrm{H}_{2} / \mathrm{N}_{2}$-reduced samples was evaluated by $\mathrm{CO}$ chemisorption due to their far better propane dehydrogenation performance than the other two samples. According to the results in Table 1 , the $48 \%$ dispersion of $\mathrm{H}_{2} / \mathrm{N}_{2}$ reduced sample is obviously higher than the $34 \%$ dispersion of the $\mathrm{C}_{3} \mathrm{H}_{8} / \mathrm{H}_{2} / \mathrm{N}_{2}$-reduced one. This indicates that the $\mathrm{H}_{2} / \mathrm{N}_{2}$-reduced catalyst had a higher utilization of Pt. Combined with the high $\mathrm{In}^{0} / \mathrm{In}^{3+}$ molar ratio and the formation of PtIn alloy in the $\mathrm{H}_{2} / \mathrm{N}_{2}$-reduced sample, it can be deduced that the Pt-In synergistic effect, high Pt dispersion and large $\operatorname{In}^{0}$ content result in good activity and high stability to some degree.

\subsection{Analysis of The Used Catalytic System}

\subsubsection{XRD}

Figure 5 shows the XRD patterns of the used catalytic system. Compared with the reduced catalytic system, the characteristic diffraction peaks of graphite (JCPDS file No. 75-1621) appear at $2 \theta$ of ca. $26^{\circ}$ and $44^{\circ}$. The peak intensity at $2 \theta$ of $26^{\circ}$ cuts down progressively following the order of the catalyst reduced with $\mathrm{C}_{3} \mathrm{H}_{8}, \mathrm{C}_{3} \mathrm{H}_{8} / \mathrm{H}_{2} / \mathrm{N}_{2}, \mathrm{CO}$ and $\mathrm{H}_{2} / \mathrm{N}_{2}$, which is correlated with the crystallinity of graphite. It can be declared that the heavily condensed coke species are more difficult to form on the $\mathrm{H}_{2} / \mathrm{N}_{2}$-reduced catalyst than others. At the same time, this also means that the $\mathrm{H}_{2} / \mathrm{N}_{2}$-reduced catalyst is easy to regenerate via oxidation in air [43]. In addition, the Pt and In species still cannot be distinguished, indicating that the metal species are quite stable and highly dispersed on the surface of PtIn/MAZ.

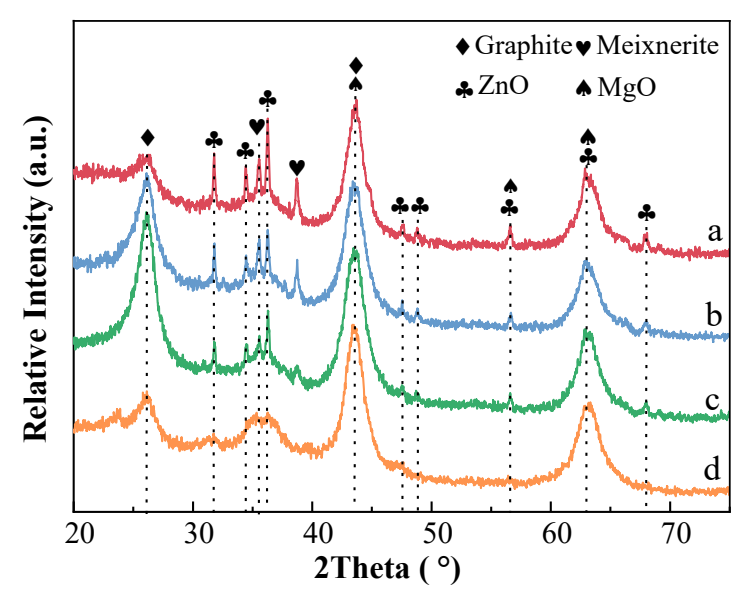

Figure 5. XRD patterns of the used PtIn/MAZ catalytic system reduced with different atmospheres: (a) $\mathrm{H}_{2} / \mathrm{N}_{2}$; (b) $\mathrm{C}_{3} \mathrm{H}_{8} / \mathrm{H}_{2} / \mathrm{N}_{2}$; (c) $\mathrm{C}_{3} \mathrm{H}_{8}$; (d) $\mathrm{CO}$ (reduction conditions: $\mathrm{T}=600{ }^{\circ} \mathrm{C}, \mathrm{t}=2.5 \mathrm{~h}$; reaction conditions: $\mathrm{T}=600{ }^{\circ} \mathrm{C}, \mathrm{WSHV}=3 \mathrm{~h}^{-1}$, atmospheric pressure in the gas mixture of $\mathrm{C}_{3} \mathrm{H}_{8}: \mathrm{H}_{2}: \mathrm{N}_{2}$ molar ratio $=8: 7: 35$ for $17 \mathrm{~h}$ ).

It is interesting to notice that the diffraction peaks of meixnerite (JCPDS file No. 38-0478) appeared at $2 \theta$ of $35^{\circ}$ and $39^{\circ}$ in the used catalytic system, instead of the reduced ones reported in [43]. This arises from the high dispersion or low content of meixnerite. On the other hand, the intensity of the corresponding diffraction peaks decreased gradually with the order of $\mathrm{H}_{2} / \mathrm{N}_{2}, \mathrm{C}_{3} \mathrm{H}_{8} / \mathrm{H}_{2} / \mathrm{N}_{2}, \mathrm{C}_{3} \mathrm{H}_{8}$ and CO-reduced sample, and even completely disappeared for PtIn/MAZ reduced with CO.

The formation of meixnerite can be explained by the reconstruction of the calcined HT under the humidified conditions [41,44-46]. As we all know, the calcination can cause $\mathrm{H}_{2} \mathrm{O}$ and $-\mathrm{OH}$ removal from the structure $[47,48]$. However some highly temperature-stable $\mathrm{M}-\mathrm{OH}_{2}$ can be formed on the 
surface of PtIn/MAZ after reduction with $\mathrm{H}$-containing gas, due to the strong water affinity of calcined HT structure [45]. It is just that the PDH reaction further provides the sufficient $-\mathrm{OH}_{2}$ concentration level and exposure time on the surface of calcined $\mathrm{HT}$, which makes the calcined $\mathrm{HT}$ reconstruct into meixnerite. Therefore, the differences of meixnerite peak intensity among the $\mathrm{H}_{2} / \mathrm{N}_{2^{-}}, \mathrm{C}_{3} \mathrm{H}_{8} / \mathrm{H}_{2} / \mathrm{N}_{2^{-}}$ and $\mathrm{C}_{3} \mathrm{H}_{8}$-reduced samples can arise from the different levels of $-\mathrm{OH}_{2}$, depending on the reducibility of these atmospheres. As a result, the strong diffraction peaks of meixnerite can be obtained by the $\mathrm{H}_{2} / \mathrm{N}_{2}$-reduced sample. The complete disappearance of meixnerite for the CO-reduced sample may have been induced by the formation of bicarbonate species, together with the consumption of oxygen, resulting in no conditions for the formation of meixnerite [36]. As a kind of HT with an interlayer $-\mathrm{OH}$ anion, the high crystallinity meixnerite may be helpful to keep the high dispersion and uniform distribution of surface metal active sites during reaction. As a result, the good stability of the $\mathrm{H}_{2} / \mathrm{N}_{2}$-reduced sample can arise from the formation of meixnerite to a certain extent [17].

Additionally, it has been proved that the meixnerite has Brønsted basicity [49], which is different from the Lewis basicity of calcined HT. Thus, the formation of meixnerite can adjust the acid-base properties of the catalyst and improve its coke resistance [50,51]. However, it is difficult to evaluate the acid-base properties by conventional methods because of the influence of deposited coke on the formed meixnerite [50,51]. As compared with the diffraction strength of meixnerite, the only direct evidence is that the diffraction strength of graphite and the amount of deposited coke (see TG analysis below) show an opposite trend in accordance with the order from $\mathrm{H}_{2} / \mathrm{N}_{2}$ - to $\mathrm{C}_{3} \mathrm{H}_{8} / \mathrm{H}_{2} / \mathrm{N}_{2}$ - and $\mathrm{C}_{3} \mathrm{H}_{8}$-reduced catalysts.

\subsubsection{TEM}

After a reaction of $17 \mathrm{~h}$, the TEM images and the PSD statistics of the used catalytic system reduced with different atmospheres are shown in Figure 6. It was found that the range of PSD became wider, but the average metal particle size only showed a slight increase compared with the corresponding reduced catalytic system. The slight aggregation of metal particles agrees with the fact that the reaction is not in the deactivation stage (Figure 1). It is worth noting that the metal sintering degree of the $\mathrm{C}_{3} \mathrm{H}_{8} / \mathrm{H}_{2} / \mathrm{N}_{2}$-reduced sample was higher than that of the $\mathrm{H}_{2} / \mathrm{N}_{2}$-reduced one, although they had similar catalytic performance during a reaction of $17 \mathrm{~h}$. Therefore, this can be used to explain the stable catalytic performance of the $\mathrm{H}_{2} / \mathrm{N}_{2}$-reduced catalyst and the rapid decline in reactivity of the $\mathrm{C}_{3} \mathrm{H}_{8} / \mathrm{H}_{2} / \mathrm{N}_{2}$-reduced sample after a reaction of $17 \mathrm{~h}$. This is attributable to the initial smaller metal particles and high Pt dispersion of the $\mathrm{H}_{2} / \mathrm{N}_{2}$-reduced catalyst. Meanwhile, it indicates strong Pt-In or Pt-support interaction, which results in the superior stability of Pt during the PDH reaction [40]. Coke deposits can be found on the support surface of the used catalytic system instead of the active site, which means that the formed coke should be shifted to the surface of support before a reaction of $17 \mathrm{~h} \mathrm{[40].}$
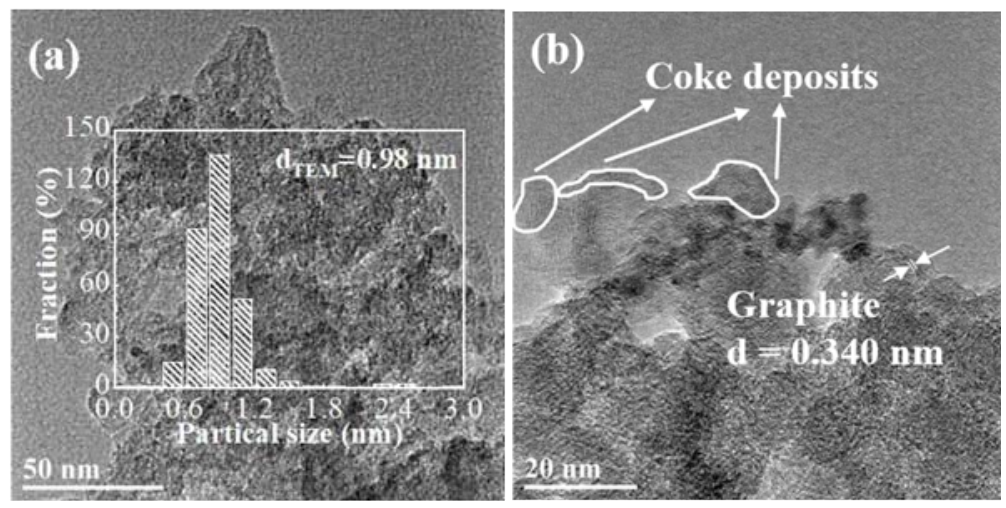

Figure 6. Cont. 

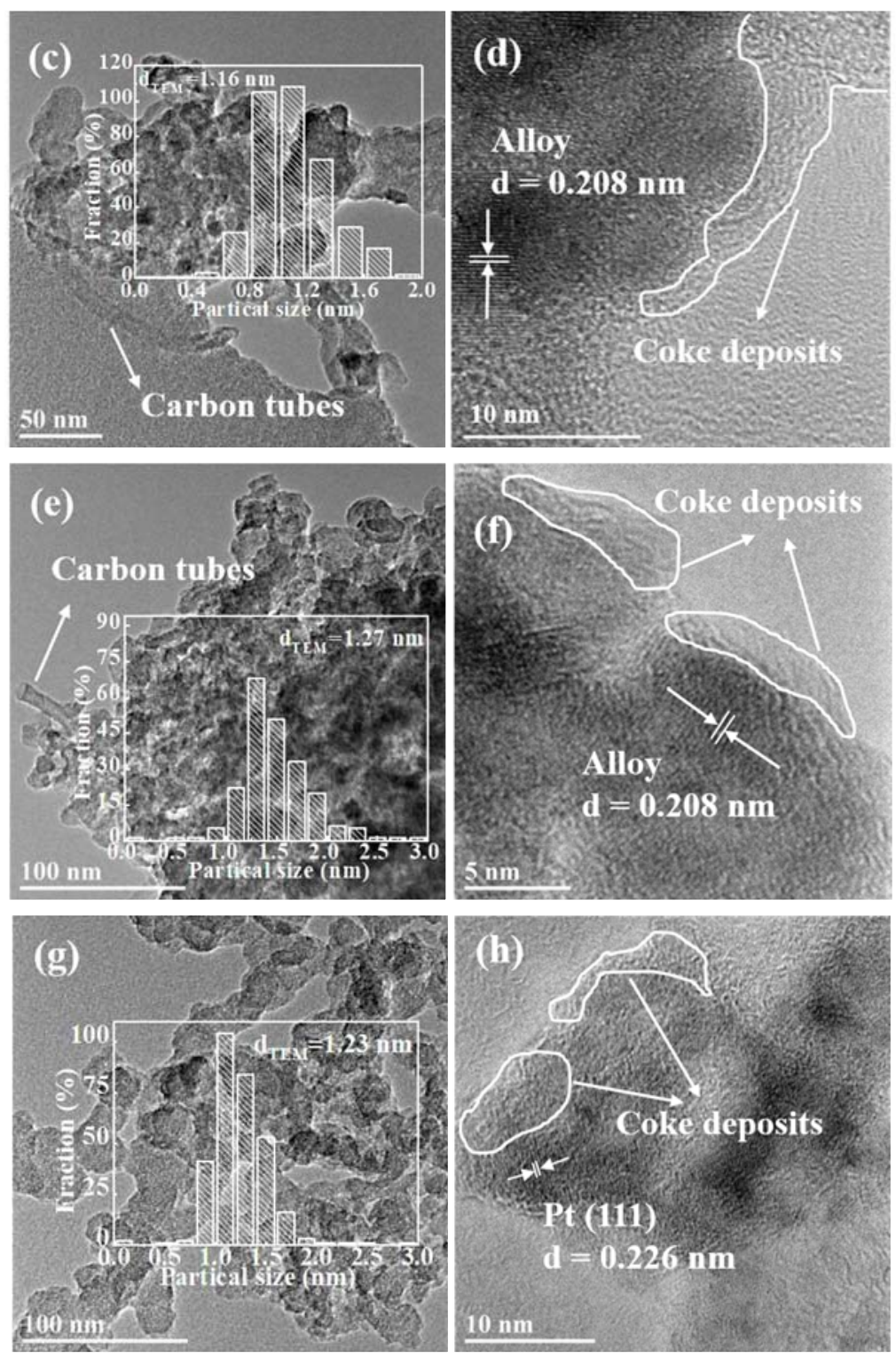

Figure 6. TEM images and the statistics of PSD in the insets of the used PtIn/MAZ catalytic system reduced with different atmospheres: (a,b) $\mathrm{H}_{2} / \mathrm{N}_{2} ;(\mathbf{c}, \mathbf{d}) \mathrm{C}_{3} \mathrm{H}_{8} / \mathrm{H}_{2} / \mathrm{N}_{2} ;(\mathbf{e}, \mathbf{f}) \mathrm{C}_{3} \mathrm{H}_{8} ;(\mathbf{g}, \mathbf{h}) \mathrm{CO}$ (reduction conditions: $\mathrm{T}=600{ }^{\circ} \mathrm{C}, \mathrm{t}=2.5 \mathrm{~h}$; reaction conditions: $\mathrm{T}=600{ }^{\circ} \mathrm{C}, \mathrm{WSHV}=3 \mathrm{~h}^{-1}$, atmospheric pressure in the gas mixture of $\mathrm{C}_{3} \mathrm{H}_{8}: \mathrm{H}_{2}: \mathrm{N}_{2}$ molar ratio $=8: 7: 35$ for $17 \mathrm{~h}$ ).

\subsubsection{TG}

In order to evaluate the amounts of deposited coke on the used catalytic system, the TG test was adopted, and the results are shown in Figure 7. The total deposited coke content of the catalyst pre-reduced with $\mathrm{H}_{2} / \mathrm{N}_{2}$ was only $27 \mathrm{wt} \%$, and lower than the others, which coincided with its high propylene selectivity (see Figure 1 ). The lowest coke formation on $\mathrm{H}_{2} / \mathrm{N}_{2}$-reduced catalyst should be related to the small metal particle size, strong Pt-In interaction and suitable acid-base properties caused by the formation of meixnerite. Meanwhile, the more $\mathrm{In}^{0}$ species also can promote the transfer of coke deposition from the active sites to the support, maintaining the stability of active metal species, ensuring the selectivity of propylene and reducing the occurrence of cracking. The pre-reduction with $\mathrm{C}_{3} \mathrm{H}_{8} / \mathrm{H}_{2} / \mathrm{N}_{2}$ and $\mathrm{C}_{3} \mathrm{H}_{8}$ made the deposited coke content increase to ca. $50 \mathrm{wt} \%$. The severe coke deposition has been proposed to explain the fast loss of activity of the $\mathrm{C}_{3} \mathrm{H}_{8} / \mathrm{H}_{2} / \mathrm{N}_{2}$-reduced sample [47]. This is thought to be related to their wide PSD [47]. The mass loss of CO-reduced catalyst is lower than the $\mathrm{C}_{3} \mathrm{H}_{8} / \mathrm{H}_{2} / \mathrm{N}_{2}$ - and $\mathrm{C}_{3} \mathrm{H}_{8}$-reduced one is, because it is far below propane conversion than them. 


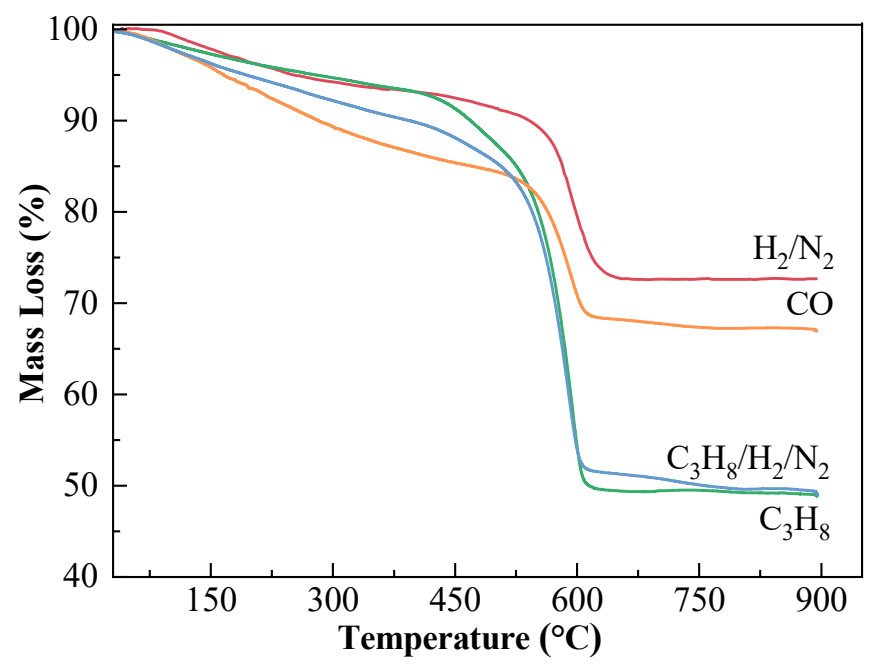

Figure 7. TG curves of the used PtIn/MAZ catalytic system reduced with different atmospheres (reduction conditions: $\mathrm{T}=600{ }^{\circ} \mathrm{C}, \mathrm{t}=2.5 \mathrm{~h}$; reaction conditions: $\mathrm{T}=600^{\circ} \mathrm{C}$, WSHV $=3 \mathrm{~h}^{-1}$, atmospheric pressure in the gas mixture of $\mathrm{C}_{3} \mathrm{H}_{8}: \mathrm{H}_{2}: \mathrm{N}_{2}$ molar ratio $=8: 7: 35$ for $17 \mathrm{~h}$ ).

In comparison with the state-of-the-art Pt-based catalysts in the literature (Table S1), the PtIn/MAZ catalytic system obtained in this work possesses much higher catalytic performance and attractive stability.

\section{Materials and Methods}

\subsection{Materials}

The reagents for the preparation of catalyst were analytical grade chemicals. $\mathrm{Zn}\left(\mathrm{NO}_{3}\right)_{2} \cdot 6 \mathrm{H}_{2} \mathrm{O}$, $\mathrm{Mg}\left(\mathrm{NO}_{3}\right)_{2} \cdot 6 \mathrm{H}_{2} \mathrm{O}, \mathrm{Al}\left(\mathrm{NO}_{3}\right)_{3} \cdot 9 \mathrm{H}_{2} \mathrm{O}$ and urea were purchased from Tianjin Fuchen Chemical Regents Factory (Tianjin, China). $\mathrm{H}_{2} \mathrm{PtCl}_{6} \cdot 6 \mathrm{H}_{2} \mathrm{O}$ was purchased from Tianjin Mascot Chemical Co. Ltd (Tianjin, China). $\mathrm{InNO}_{3} \cdot \mathrm{xH}_{2} \mathrm{O}$ was purchased from Aladdin Industrial corporation (Shanghai, China).

\subsection{Preparation of $\mathrm{ZnO}$ Precursor}

The $\mathrm{ZnO}$ precursor was prepared by the hydrothermal method. Briefly, $0.004 \mathrm{~mol}$ of $\mathrm{Zn}\left(\mathrm{NO}_{3}\right)_{2} \cdot 6 \mathrm{H}_{2} \mathrm{O}$ and $0.083 \mathrm{~mol}$ of urea was fully dissolved in $65 \mathrm{~mL}$ deionized water, then moved to a Teflon-lined stainless steel autoclave at $100{ }^{\circ} \mathrm{C}$ for $20 \mathrm{~h}$. After cooling to room temperature, the products were filtrated and washed with deionized water till neutrality, then dried at $100{ }^{\circ} \mathrm{C}$ overnight to obtain the $\mathrm{ZnO}$ precursor.

\subsection{Preparation of MAZ Support}

The $\mathrm{Mg}(\mathrm{Al}) \mathrm{O} / \mathrm{ZnO}$ (MAZ) precursor was prepared by the hydrothermal method. The molar ratio of $\mathrm{Mg} / \mathrm{Al}$ is 2. Firstly, $0.1 \mathrm{~g}$ of $\mathrm{ZnO}$ precursor was introduced in $65 \mathrm{~mL}$ of a mixed solution, including $0.003 \mathrm{~mol}$ of $\mathrm{Mg}\left(\mathrm{NO}_{3}\right)_{2} \cdot 6 \mathrm{H}_{2} \mathrm{O}, 0.0015 \mathrm{~mol}$ of $\mathrm{Al}\left(\mathrm{NO}_{3}\right)_{3} \cdot 9 \mathrm{H}_{2} \mathrm{O}$ and $0.1 \mathrm{~mol}$ of urea under vigorous stirring. After hydrothermal treatment in a Teflon-lined stainless-steel autoclave at $100{ }^{\circ} \mathrm{C}$ for $20 \mathrm{~h}$, the mixture was cooled to room temperature. Next, the slurry was filtrated and washed with deionized water till to neutrality, then dried at $100{ }^{\circ} \mathrm{C}$ overnight. Finally, the corresponding MAZ support was obtained by calcining the precursor at $600{ }^{\circ} \mathrm{C}$ for $4 \mathrm{~h}$ in a muffle furnace with a heating rate of $5{ }^{\circ} \mathrm{C} \mathrm{min}^{-1}$.

\subsection{Preparation and Reduction of PtIn/MAZ}

The PtIn/MAZ precursor was synthesized via successive incipient wetness impregnation method. Firstly, the MAZ support was impregnated with an $\mathrm{InNO}_{3} \cdot \mathrm{xH}_{2} \mathrm{O}$ aqueous solution at room temperature 
for $6 \mathrm{~h}$ and dried at $120^{\circ} \mathrm{C}$ for $12 \mathrm{~h}$ to acquire the $\mathrm{In} / \mathrm{MAZ}$ precursor. After calcination at $550{ }^{\circ} \mathrm{C}$ for $4 \mathrm{~h}$, the In-based calcined product was obtained and labelled as In/MAZ. Next, the same processes were performed on In/MAZ by impregnating with an $\mathrm{H}_{2} \mathrm{PtCl}_{6} \cdot 6 \mathrm{H}_{2} \mathrm{O}$ aqueous solution to acquire the PtIn/MAZ precursor.

The calcined product PtIn/MAZ was obtained by calcining the corresponding precursor at $550{ }^{\circ} \mathrm{C}$ for $4 \mathrm{~h}$ with a heating rate of $5^{\circ} \mathrm{C} \mathrm{min}^{-1}[19,41]$. To be consistent with previous research [22], the loading amounts of $\mathrm{Pt}$ and In were $0.5 \mathrm{wt} \%$ and $1.4 \mathrm{wt} \%$, respectively.

Before the $\mathrm{PDH}$ reaction, $\mathrm{PtIn} / \mathrm{MAZ}$ was reduced with different atmospheres. The reduction atmospheres of $\mathrm{H}_{2} / \mathrm{N}_{2}\left(5 \mathrm{vol} \% \mathrm{H}_{2}\right), \mathrm{C}_{3} \mathrm{H}_{8} / \mathrm{H}_{2} / \mathrm{N}_{2}\left(16 \mathrm{vol} \% \mathrm{C}_{3} \mathrm{H}_{8}\right.$ and $\left.14 \mathrm{vol} \% \mathrm{H}_{2}\right), \mathrm{C}_{3} \mathrm{H}_{8}$ and $\mathrm{CO}$ were used to reduce PtIn/MAZ at $600{ }^{\circ} \mathrm{C}$ for $2.5 \mathrm{~h}$ respectively. In order to compare with $\mathrm{H}_{2} / \mathrm{N}_{2}(5 \mathrm{vol} \%$ $\left.\mathrm{H}_{2}\right)$ and $\mathrm{C}_{3} \mathrm{H}_{8} / \mathrm{H}_{2} / \mathrm{N}_{2}\left(16 \mathrm{vol} \% \mathrm{C}_{3} \mathrm{H}_{8}\right.$ and $\left.14 \mathrm{vol} \% \mathrm{H}_{2}\right)$, the reduction gas of $14 \mathrm{vol} \% \mathrm{H}_{2} / \mathrm{N}_{2}$ was also evaluated in the $\mathrm{PDH}$ reaction.

\subsection{Catalyst Characterizations}

The X-ray diffraction (XRD) patterns were recorded on a Bruker D8-Focus X-ray diffractometer (BRUKER AXS GMBH, Karlsruhe, Germany) equipped with $\mathrm{Cu} \mathrm{K} \alpha$ radiation $(\lambda=0.15418 \mathrm{~nm})$. The samples were scanned from the $2 \theta$ value of $20^{\circ}-75^{\circ}$, with a scanning speed of $8^{\circ} \cdot \mathrm{min}^{-1}$. The X-ray tube was manipulated at $40 \mathrm{kV}$ and $40 \mathrm{~mA}$.

The transmission electron microscopy (TEM) images were taken with a JEM-2100F field-emission transmission electron microscope (JEOL, Tokyo, Japan) operated at $200 \mathrm{kV}$. The as-synthesized samples were dispersed, sonicated in ethanol, and dropped on carbon-film coated copper grids.

X-ray photoelectron spectroscopy (XPS) was carried out on a Perkin-Elmer PHI 5000C ESCA (PerkinElmer, Waltham, MA, USA) using Al K $\alpha$ radiation. Prior to the analysis, the samples were reduced under different atmospheres $\left(30 \mathrm{~mL} \mathrm{~min}^{-1}\right)$ at $600{ }^{\circ} \mathrm{C}$ for $2.5 \mathrm{~h}$, and the binding energies were calibrated using the $\mathrm{C} 1 \mathrm{~s}$ peak at $284.8 \mathrm{eV}$ as an internal standard. The whole process from reduction to test was strictly protected with Ar, which can avoid the re-oxidation of $\mathrm{In}^{0}$.

Thermogravimetric (TG) analysis was carried out with a DTG-50/50H thermal analyzer (PerkinElmer, Waltham, MA, USA) to determine the quantity of coke on the used catalyst, and the TG curves were recorded from room temperature to $900{ }^{\circ} \mathrm{C}$ at an increasing rate of $10{ }^{\circ} \mathrm{C} \mathrm{min}{ }^{-1}$.

Dispersion of metals was determined by CO chemisorption, $\mathrm{CO}$ chemisorption was conducted on AutoChem II 2920 analyzer (Micromeritics, Norcross, GA, USA). For a fresh catalyst, $100 \mathrm{mg}$ of sample was pre-reduced with different atmospheres at $600^{\circ} \mathrm{C}$ for $2.5 \mathrm{~h}$ and then purged with Ar flow at $300^{\circ} \mathrm{C}$ for $0.5 \mathrm{~h}$. CO chemisorption was carried out at $30^{\circ} \mathrm{C}$ by injecting $50 \mu \mathrm{L} \mathrm{CO}$ every 3 min until the peak area became stable. The adsorption capacity of $\mathrm{CO}$ is calculated by the following Equation.

$$
\text { CO uptakes }\left(\mu \mathrm{mol} \mathrm{g}^{-1}{ }_{\text {cat }}\right)=n \times(A-B) \times 50 \times 10 / A \times 22.4
$$

where $n$ stands for the number of chemical adsorption peaks, $A$ represents the average value of the peak area when the peak area remains constant, and $B$ stands for the total area of the chemical adsorption peaks.

\subsection{Catalytic Measurements}

The PDH reactions were carried out in a fixed-bed quartz reactor with an 8-mm inner diameter. A quantity of $0.4 \mathrm{~g}$ of fresh catalyst (particle size of 40 to 60 meshes) was placed into the center of quartz tube reactor and reduced with different reduction atmospheres, as described in Section 2.3. Afterwards, the mixed gas, including $\mathrm{C}_{3} \mathrm{H}_{8}, \mathrm{H}_{2}$ and $\mathrm{N}_{2}\left(\mathrm{C}_{3} \mathrm{H}_{8}: \mathrm{H}_{2}: \mathrm{N}_{2}\right.$ molar ratio = 8:7:35), was fed at a rate of $62 \mathrm{~mL} \mathrm{~min}^{-1}$ into the reactor. The $\mathrm{PDH}$ reactions were performed at atmospheric pressure, $600{ }^{\circ} \mathrm{C}$ and a weight hourly space velocity (WHSV) of $3 \mathrm{~h}^{-1}$, which was generally used in relevant studies $[21,52,53]$. A gas chromatograph equipped with an FID detector and $\mathrm{Al}_{2} \mathrm{O}_{3}$ column was 
employed to analyze the gas compositions. The propane conversion and propylene selectivity were calculated by the following Equations:

$$
\begin{aligned}
& \text { Conversion }(\%)=\frac{\text { propane, in - propane, out }}{\text { propane, in }} \times 100 \\
& \text { Selectivity }(\%)=\frac{\text { propylene, out }}{\text { propane, in - propane, out }} \times 100
\end{aligned}
$$

\section{Conclusions}

A catalyst, $\mathrm{PtIn} / \mathrm{Mg}(\mathrm{Al}) \mathrm{O} / \mathrm{ZnO}$, can be obtained by calcination and reduction of $\mathrm{ZnO}$-supported PtIn-HT. The reduction atmosphere has a profound influence on the physicochemical nature and catalytic performance of the $\mathrm{PtIn} / \mathrm{Mg}(\mathrm{Al}) \mathrm{O} / \mathrm{ZnO}$ catalyst. The propane conversion and propylene selectivity of the catalyst reduced with $\mathrm{H}_{2} / \mathrm{N}_{2}$ can reach $51 \%$ and $97 \%$, respectively, and even stabilize at $45 \%$ and $92 \%$ after running for $30 \mathrm{~h}$. This is mainly attributable to its high Pt dispersion and $\operatorname{In}^{0} / \mathrm{In}^{3+}$ molar ratio, strong Pt-In interaction and small metal particle size, which also result in a low content of coke deposits on the surface of the $\mathrm{H}_{2} / \mathrm{N}_{2}$-reduced catalyst. In addition, meixnerite can be formed after the reaction, and the crystallinity is influenced by the reduction atmosphere. At the same time, the formation of the high-crystallinity meixnerite can re-disperse the metal active sites and adjust the acid-base properties of the catalyst, thus improving the stability and coke resistance to some extent.

Supplementary Materials: The following are available online at http://www.mdpi.com/2073-4344/10/5/485/s1, Figure S1: XRD patterns of precursors (A) and the corresponding calcined samples (B): (a) ZnO; (b) MAZ; (c) In/MAZ; (d) PtIn/MAZ. Table S1. Comparison of the catalytic performance of some state-of-the-art catalysts used in propane dehydrogenation.

Author Contributions: M.Z. wrote the manuscript, performed the experiments and analyzed data; M.Z., Z.S. and M.G. collected references and characterized the physic-chemical properties of materials; X.L. collected and checked data; Y.L. analyzed data and checked the manuscript; L.Z. provided research ideas, analyzed data and revised the manuscript. All authors have read and agreed to the published version of the manuscript.

Funding: This research was funded by National Natural Science Foundation of China $(21776214,21776018)$.

Conflicts of Interest: The authors declare no conflict of interest.

\section{References}

1. Sun, P.; Siddiqi, G.; Chi, M.; Bell, A.T. Synthesis and characterization of a new catalyst $\mathrm{Pt} / \mathrm{Mg}(\mathrm{Ga})(\mathrm{Al}) \mathrm{O}$ for alkane dehydrogenation. J. Catal. 2010, 274, 192-199. [CrossRef]

2. Sahebdelfar, S.; Bijani, P.M.; Saeedizad, M.; Zangeneh, F.T.; Ganji, K. Modeling of adiabatic moving-bed reactor for dehydrogenation of isobutane to isobutene. Appl. Catal. A 2011, 395, 107-113. [CrossRef]

3. Caeiro, G.; Carvalho, R.H.; Wang, X.; Lemos, M.A.N.D.; Lemos, F.; Guisnet, M.; Ramôa Ribeiro, F. Activation of C2-C4 alkanes over acid and bifunctional zeolite catalysts. J. Mol. Catal. A Chem. 2006, 255, 131-158. [CrossRef]

4. Schäferhans, J.; Gómez-Quero, S.; Aneeva, D.V.; Rothenberg, G. Novel and effective copper-aluminum propane dehydrogenation catalysts. Chem.-Eur. J. 2011, 17, 12254-12256. [CrossRef] [PubMed]

5. Beckers, J.; Rothenberg, G. Sustainable selective oxidations using ceria-based materials. Green Chem. 2010, 12, 939-948. [CrossRef]

6. Hu, B.; Bean Getsoian, A.; Schweitzer, N.M.; Das, U.; Kim, H.; Niklas, J.; Poluektov, O.; Curtiss, L.A.; Stair, P.C.; Miller, J.T.; et al. Selective propane dehydrogenation with single-site CoII on $\mathrm{SiO}_{2}$ by a non-redox mechanism. J. Catal. 2015, 322, 24-37. [CrossRef]

7. Pakhomov, N.A. Reversible and Irreversible Deactivation of Supported Bimetallic Catalysts for the Dehydrogenation of Lower Paraffins. Kinet. Catal. 2001, 42, 334-343. [CrossRef]

8. De Miguel, S.; Castro, A.; Scelza, O.; Fierro, J.L.G.; Soria, J. FTIR and XPS study of supported PtSn catalysts used for light paraffins dehydrogenation. Catal. Lett. 1996, 36, 201-206. [CrossRef] 
9. Jablonski, E.L.; Castro, A.A.; Scelza, O.A.; de Miguel, S.R. Effect of Ga addition to $\mathrm{Pt} / \mathrm{Al}_{2} \mathrm{O}_{3}$ on the activity, selectivity and deactivation in the propane dehydrogenation. Appl. Catal. A 1999, 183, 189-198. [CrossRef]

10. Homs, N.; Llorca, J.; Riera, M.; Jolis, J.; Fierro, J.G.; Sales, J.; de la Piscina, P.R. Silica-supported PtSn alloy doped with Ga, In or, Tl: Characterization and catalytic behavior in n-hexane dehydrogenation. J. Mol. Catal. A Chem. 2003, 200, 251-259. [CrossRef]

11. Chen, M.; Xu, J.; Cao, Y.; He, H.; Fan, K.; Zhuang, J. Dehydrogenation of propane over $\operatorname{In}_{2} \mathrm{O}_{3}-\mathrm{Al}_{2} \mathrm{O}_{3}$ mixed oxide in the presence of carbon dioxide. J. Catal. 2010, 272, 101-108. [CrossRef]

12. Hoang, D.L.; Farrage, S.A.F.; Radnik, J.; Pohl, M.M.; Schneider, M.; Lieske, H.; Martin, A. A comparative study of zirconia and alumina supported $\mathrm{Pt}$ and $\mathrm{Pt}-\mathrm{Sn}$ catalysts used for dehydrocyclization of $n$-octane. Appl. Catal. A 2007, 333, 67-77. [CrossRef]

13. Liu, Y.; Xia, C.; Wang, Q.; Zhang, L.; Huang, A.; Ke, M.; Song, Z. Direct dehydrogenation of isobutane to isobutene over $\mathrm{Zn}$-doped $\mathrm{ZrO}_{2}$ metal oxide heterogeneous catalysts. Catal. Sci. Technol. 2018, 8, 4916-4924. [CrossRef]

14. Azzam, K.G.; Jacobs, G.; Shafer, W.D.; Davis, B.H. Dehydrogenation of propane over Pt/KL catalyst: Investigating the role of L-zeolite structure on catalyst performance using isotope labeling. Appl. Catal. A 2010, 390, 264-270. [CrossRef]

15. Sun, P.; Siddiqi, G.; Vining, W.C.; Chi, M.; Bell, A.T. Novel Pt/Mg(In)(Al)O catalysts for ethane and propane dehydrogenation. J. Catal. 2011, 282, 165-174. [CrossRef]

16. Li, Y.; Li, J.; Yang, X.; Wang, X.; Xu, Y.; Zhang, L. Preparation of $\mathrm{CeO}_{2}-\mathrm{Modified} \mathrm{Mg(Al)O-Supported}$ $\mathrm{Pt}-\mathrm{Cu}$ Alloy Catalysts Derived from Hydrotalcite-Like Precursors and Their Catalytic Behavior for Direct Dehydrogenation of Propane. Trans. Tianjin Univ. 2019, 25, 169-184. [CrossRef]

17. Zhu, Y.; An, Z.; Song, H.; Xiang, X.; Yan, W.; He, J. Lattice-Confined Sn (IV/II) Stabilizing Raft-Like Pt Clusters: High Selectivity and Durability in Propane Dehydrogenation. Acs Catal. 2017, 7, 6973-6978. [CrossRef]

18. Gao, S.; Lu, T.; Li, S.; Zhong, H. The mechanism on the $\mathrm{pH}$ value influencing the property of glutamic acid/layered double hydroxide compounds. Colloids Surf. A 2009, 351, 26-29. [CrossRef]

19. Xia, K.; Lang, W.; Li, P.; Long, L.; Yan, X.; Guo, Y. The influences of MgAl molar ratio on the properties of PtInMg(Al)O-x catalysts for propane dehydrogenation reaction. Chem. Eng. J. 2016, 284, 1068-1079. [CrossRef]

20. Mascolo, G.; Mascolo, M.C. On the synthesis of layered double hydroxides (LDHs) by reconstruction method based on the "memory effect". Micropor. Mesopor. Mater. 2015, 214, 246-248. [CrossRef]

21. Xia, K.; Lang, W.; Li, P.; Yan, X.; Guo, Y. The properties and catalytic performance of PtIn/Mg(Al)O catalysts for the propane dehydrogenation reaction: Effects of $\mathrm{pH}$ value in preparing $\mathrm{Mg}(\mathrm{Al}) \mathrm{O}$ supports by the co-precipitation method. J. Catal. 2016, 338, 104-114. [CrossRef]

22. Li, J.; Zhang, M.; Song, Z.; Liu, S.; Wang, J.; Zhang, L. Hierarchical PtIn/Mg(Al)O Derived from Reconstructed PtIn-hydrotalcite-like Compounds for Highly Efficient Propane Dehydrogenation. Catalysts 2019, 9, 767. [CrossRef]

23. Gao, Z.; Sasaki, K.; Qiu, X. Structural Memory Effect of Mg-Al and Zn-Al layered Double Hydroxides in the Presence of Different Natural Humic Acids: Process and Mechanism. Langmuir 2018, 34, 5386-5395. [CrossRef] [PubMed]

24. Ping, J.; Wang, Y.; Lu, Q.; Chen, B.; Chen, J.; Huang, Y.; Ma, Q.; Tan, C.; Yang, J.; Cao, X.; et al. Self-Assembly of Single-Layer CoAl-Layered Double Hydroxide Nanosheets on 3D Graphene Network Used as Highly Efficient Electrocatalyst for Oxygen Evolution Reaction. Adv. Mater. 2016, 28, 7640-7645. [CrossRef]

25. Yang, S.; Zhang, Z.; Zhou, J.; Sui, Z.; Zhou, X. Hierarchical NiCo LDH-rGO/Ni Foam Composite as Electrode Material for High-Performance Supercapacitors. Trans. Tianjin Univ. 2019, 25, 266-275. [CrossRef]

26. Jiang, J.; Zhu, J.; Ding, R.; Li, Y.; Wu, F.; Liu, J.; Huang, X. Co-Fe layered double hydroxide nanowall array grown from an alloy substrate and its calcined product as a composite anode for lithium-ion batteries. J. Mater. Chem. 2011, 21, 15969. [CrossRef]

27. Zhu, Y.; An, Z.; He, J. Single-atom and small-cluster Pt induced by Sn (IV) sites confined in an LDH lattice for catalytic reforming. J. Catal. 2016, 341, 44-54. [CrossRef]

28. Chen, X.; Chen, X.; Wang, L.; Wang, L.; Qin, H.; Qin, H.; Yang, Z.; Yang, Z. Fabrication and electrochemical performance of flower-like $\mathrm{ZnAl} \mathrm{LDH} / \mathrm{SnO}_{2}$ composites for zinc-nickel secondary batteries. Ionics 2019, 25, 1715-1724. [CrossRef] 
29. Wang, F.; Liu, M.; Zhang, X.; Lv, G.; Sun, M. In Situ Growth of 3D Hierarchical ZnO@Ni $\mathrm{Zn}_{1-\mathrm{x}}(\mathrm{OH})_{\mathrm{y}}$ Core/Shell Nanowire/Nanosheet Arrays on Ni Foam for High-Performance Aqueous Hybrid Supercapacitors. Trans. Tianjin Univ. 2018, 24, 201-211. [CrossRef]

30. Shen, L.; Xia, K.; Lang, W.; Chu, L.; Yan, X.; Guo, Y. The effects of calcination temperature of support on $\mathrm{PtIn} / \mathrm{Mg}(\mathrm{Al}) \mathrm{O}$ catalysts for propane dehydrogenation reaction. Chem. Eng. J. 2017, 324, 336-346. [CrossRef]

31. Yang, Y.; Fan, G.; Li, F. Synthesis of novel marigold-like carbonate-type Mg-Al layered double hydroxide micro-nanostructures via a two-step intercalation route. Mater. Lett. 2014, 116, 203-205. [CrossRef]

32. Filez, M.; Redekop, E.A.; Poelman, H.; Galvita, V.V.; Meledina, M.; Turner, S.; Van Tendeloo, G.; Detavernier, C.; Marin, G.B. One-pot synthesis of Pt catalysts based on layered double hydroxides: An application in propane dehydrogenation. Catal. Sci. Technol. 2016, 6, 1863-1869. [CrossRef]

33. Stepanova, L.N.; Belskaya, O.B.; Likholobov, V.A. Effect of the Nature of the Active-Component Precursor on the Properties of $\mathrm{Pt} / \mathrm{MgAlO}$ Catalysts in Propane and $n$-Decane Dehydrogenation. Kinet. Catal. 2017, 4, 400-409. [CrossRef]

34. Wu, J.; Peng, Z.; Sun, P.; Bell, A.T. n-Butane dehydrogenation over Pt/Mg(In)(Al)O. Appl. Catal. A 2014, 470, 208-214. [CrossRef]

35. Larsson, M.; Hultén, M.; Blekkan, E.A.; Andersson, B. The Effect of Reaction Conditions and Time on Stream on the Coke Formed during Propane Dehydrogenation. J. Catal. 1996, 164, 44-53. [CrossRef]

36. Airaksinen, S.M.K.; Krause, A.O.I.; Sainio, J.; Lahtinen, J.; Chao, K.; Ares, M.O.G.R. Reduction of chromia/alumina catalyst monitored by DRIFTS-mass spectrometry and TPR-Raman spectroscopy. Phys. Chem. Chem. Phys. 2003, 20, 4371-4377. [CrossRef]

37. Hakuli, A.; Kytokivi, A.; Krause, A.O.I.; Suntola, T. Initial Activity of Reduced Chromia/Alumina Catalyst in n-Butane Dehydrogenation Monitored by On-Line FT-IR Gas Analysis. J. Catal. 1996, 161, 393-400. [CrossRef]

38. Galvita, V.; Siddiqi, G.; Sun, P.; Bell, A.T. Ethane dehydrogenation on Pt/Mg(Al)O and PtSn/Mg(Al)O catalysts. J. Catal. 2010, 271, 209-219. [CrossRef]

39. Santhosh Kumar, M.; Chen, D.; Walmsley, J.C.; Holmen, A. Dehydrogenation of propane over Pt-SBA-15: Effect of Pt particle size. Catal. Commun. 2008, 9, 747-750. [CrossRef]

40. Chen, X.; Ge, M.; Li, Y.; Liu, Y.; Wang, J.; Zhang, L. Fabrication of highly dispersed Pt-based catalysts on $\gamma-\mathrm{Al}_{2} \mathrm{O}_{3}$ supported perovskite Nano islands: High durability and tolerance to coke deposition in propane dehydrogenation. Appl. Surf. Sci. 2019, 490, 611-621. [CrossRef]

41. Xia, K.; Lang, W.; Li, P.; Yan, X.; Guo, Y. Analysis of the catalytic activity induction and deactivation of $\mathrm{PtIn} / \mathrm{Mg}(\mathrm{Al}) \mathrm{O}$ catalysts for propane dehydrogenation reaction. Rsc Adv. 2015, 5, 64689-64695. [CrossRef]

42. Wang, T.; Jiang, F.; Liu, G.; Zeng, L.; Zhao, Z.J.; Gong, J. Effects of Ga doping on Pt/ $\mathrm{CeO}_{2}-\mathrm{Al}_{2} \mathrm{O}_{3}$ catalysts for propane dehydrogenation. Aiche J. 2016, 62, 4365-4376. [CrossRef]

43. Yu, J.; Wang, R.; Ren, S.; Sun, X.; Chen, C.; Ge, Q.; Fang, W.; Zhang, J.; Xu, H.; Su, D.S. The Unique Role of $\mathrm{CaO}$ in Stabilizing the $\mathrm{Pt} / \mathrm{Al}_{2} \mathrm{O}_{3}$ Catalyst for the Dehydrogenation of Cyclohexane. Chemcatchem 2012, 4, 1376-1381. [CrossRef]

44. Mitchell, P.C.H.; Wass, S.A. Propane dehydrogenation over molybdenum hydrotalcite catalysts. Appl. Catal. A 2002, 225, 153-165. [CrossRef]

45. Mokhtar, M.; Inayat, A.; Ofili, J.; Schwieger, W. Thermal decomposition, gas phase hydration and liquid phase reconstruction in the system $\mathrm{Mg} / \mathrm{Al}$ hydrotalcite/mixed oxide: A comparative study. Appl. Clay Sci. 2010, 50, 176-181. [CrossRef]

46. Pérez-Ramírez, J.; Abelló, S.; van der Pers, N.M. Memory Effect of Activated Mg-Al Hydrotalcite: In Situ XRD Studies during Decomposition and Gas-Phase Reconstruction. Chem.-Eur. J. 2007, 13, 870-878. [CrossRef]

47. Airaksinen, S.M.K.; Harlin, M.E.; Krause, A.O.I. Kinetic Modeling of Dehydrogenation of Isobutane on Chromia/Alumina Catalyst. Ind. Eng. Chem. Res. 2002, 41, 5619-5626. [CrossRef]

48. Derossi, S.; Ferraris, G.; Fremiotti, S.; Garrone, E.; Ghiotti, G.; Campa, M.C.; Indovina, V. Propane Dehydrogenation on Chromia/Silica and Chromia/Alumina catalysts. J. Catal. 1994, 148, 36-46. [CrossRef]

49. Prinetto, F.; Ghiotti, G.; Durand, R.; Tichit, D. Investigation of Acid-Base Properties of Catalysts Obtained from Layered Double Hydroxides. J. Phys. Chem. B 2000, 104, 11117-11126. [CrossRef]

50. Mounfield, W.P.; Claure, M.T.; Agrawal, P.K.; Jones, C.W.; Walton, K.S. Synergistic Effect of Mixed Oxide on the Adsorption of Ammonia with Metal-Organic Frameworks. Ind. Eng. Chem. Res. 2016, 22, 6492-6500. [CrossRef] 
51. Rao, K.K.; Gravelle, M.; Valente, J.S.; Figueras, F. Activation of Mg-Al Hydrotalcite Catalysts for Aldol Condensation Reactions. J. Catal. 1998, 173, 115-121. [CrossRef]

52. Liu, G.; Zhao, Z.; Wu, T.; Zeng, L.; Gong, J. Nature of the Active Sites of $\mathrm{VO}_{\mathrm{x}} / \mathrm{Al}_{2} \mathrm{O}_{3}$ Catalysts for Propane Dehydrogenation. Acs Catal. 2016, 6, 5207-5214. [CrossRef]

53. Han, Z.; Li, S.; Jiang, F.; Wang, T.; Ma, X.; Gong, J. Propane dehydrogenation over Pt-Cu bimetallic catalysts: The nature of coke deposition and the role of copper. Nanoscale 2014, 6, 1-18. [CrossRef] [PubMed]

(C) 2020 by the authors. Licensee MDPI, Basel, Switzerland. This article is an open access article distributed under the terms and conditions of the Creative Commons Attribution (CC BY) license (http://creativecommons.org/licenses/by/4.0/). 